The Humane Society Institute for Science and Policy Animal Studies Repository

$12-1972$

\title{
The Development of Social Interaction, Play, and Metacommunication in Mammals: An Ethological Perspective
}

Marc Bekoff

Washington University, marc.bekoff@gmail.com

Follow this and additional works at: http://animalstudiesrepository.org/acwp_ena

Part of the Animal Studies Commons, Behavior and Ethology Commons, and the Comparative Psychology Commons

\section{Recommended Citation}

Bekoff, M. (1972). The development of social interaction, play, and metacommunication in mammals: an ethological perspective. Quarterly Review of Biology, 412-434.

This Article is brought to you for free and open access by the Humane Society Institute for Science and Policy. It has been accepted for inclusion by an authorized administrator of the Animal Studies Repository. For more information, please contact eyahner@humanesociety.org. 


\title{
THE DEVELOPMENT OF SOCIAL INTERACTION, PLAY, AND METACOMMUNICATION IN MAMMALS: AN ETHOLOGICAL PERSPECTIVE
}

\author{
By MARC BEKOFF \\ Department of Psychology, Washington University \\ St. Louis, Missouri 63130
}

\begin{abstract}
Analysis of the dynamics of the ontogeny of social interaction is of critical importance in order that behavioral development may be comprehended in its own right, and the relationship between infant and adult behavior understood. In this review, general concepts of behavioral development in mammals are discussed and analyzed, and the many variables that are involved are considered. When it is impossible to control or observe the social interaction of the developing organism in its natural environment, captive subjects should be used. There is increasing evidence that results obtained with the latter are related to social organization observed in the wild.

Play behavior is operationally defined on the basis of a comprehensive review of the literature and of personal observations of the social development of canids. The essential "need" for social interaction during infant life is discussed, as is the phenomenon of behavioral neoteny. The concept of metacommunication, and its relationship to social development are analyzed, and the role of ritualization in the evolution of metacommunicative signals is considered.
\end{abstract}

GENERAL CONCEPTS OF BEHAVIORAL ONTOGENY

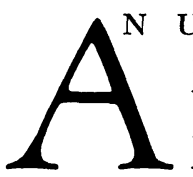

UNDERSTANDING of the dynamics of the ontogeny of social behavior is of critical importance to evaluation of adult behavior. Recently this problem has been extensively reviewed in volumes by Foss (1961, 1963, 1965, 1969), Newton and Levine (1968), Bowlby (1969), Mussen (1970), Tobach, Aronson, and Shaw (1971), Moltz 1971a), Schaffer (1971), and Denenberg (1972). Fox (1971a) has recently reviewed the literature and has also presented original experiments concerned with understanding the integrative development of brain and behavior in canids, and Horwich (1972) has studied the ontogeny of social behavior in the gray squirrel in great detail. Russian contributions to the field of behavioral ontogeny have recently been reviewed and summarized by Kovach (1971) and by Slonim $(1969,1972)$.
All behavior presents us with a problem in development (Manning, 1971). In order to be able to understand adult social behavior, we must know something of its development (Clark, Wyon, and Richards, 1969), and the study of development cannot be separated from the study of the functions of the adult animal (Tinbergen, 1951). However, attempts to analyze social interaction and social developmental processes in infants in terms of char. acteristics that are only applicable to experienced organisms produce misleading and often meaningless results (Bekoff, 1972). As Welker (1971) has stressed, concepts based entirely on behavioral phenomena of mature animals cannot be used in understanding the behavior of neonatal animals. Indeed, the mature behavioral repertoire itself can be understood fully only if its ontogenetic origins are known (Welker, 1971). The behavior of a child must be viewed as being adapted toward 
survival as a child, as well as toward acquiring information for later life (Blurton Jones, 1972a).

The use of the comparative approach (e.g., Lorenz, 1950) is valuable. By comparatively studying behavioral development, a comprehension of the causation and function of species-characteristic behavior patterns may be realized. Lehrman (1962) wrote that a full understanding of the organization and causation of behavior patterns can only be achieved by analysis of ontogeny; and Schneirla (1966) declared that behavioral ontogenesis is the backbone of comparative psychology. Therefore, the comparative ontogenetic approach is a powerful tool for studying social behavior.

The two most important aspects of the ontogeny of social behavior are (1) the development of control of agonistic behavior (e.g., Scott, 1958) and the formation of dominance relationships; and (2) the development of nonagonistic social interactions (Bekoff, 1972). Although the present review is concerned with the latter aspect, it must be stressed that an overall analysis of the development of social interaction must account for both. For example, social deprivation experiments not only deprive the developing organism of playful interactions, as is so often suggested (see Glickman and Sroges, 1966), but of all types of social intercourse (see below).

The initial step of any developmental (and behavioral) study should be the establishment of ethograms (a behavioral repertoire) and sociograms of the animal (s) under study (Tinbergen, 1951; Russell, Mead, and Hayes, 1954; Hutt and Hutt, 1970). Smith and Connelly (1972) have emphasized this point by writing that the most powerful tool in the ethologist's armory is the description of specific motor patterns. To avoid premature (and irrelevant) experimental manipulation, it must be known what behavior there is to be modified (Hutt and Hutt, 1970), and also the normal range of individual differences within a given species.

A representative ethogram is presented in Table 1 (after Bekoff, 1972). Nelson (1964) has correctly pointed out that it is important to realize that an analysis of behavior may involve units as small as a muscle twitch or as large as an entire pattern such as migration. For behavioral studies concerned with in- vestigating social interaction, the unit of analysis should involve discrete motor action patterns (e.g., Wiepkema, 1961; Grant, 1963; Nelson, 1964; Altmann, 1965; Poole, 1966, 1967, 1972; Lerwill and Makings, 1971; Reynierse, 1971; Stanley, 1971; Fox and Clark, 1971; Bekoff, 1972; Blurton Jones, 1972b; McGrew, 1972) that are relatively simple, observable, and measurable (Welker, 1971). In this way, the time of first appearance of specific actions (and sequences) may be noted, and changes over time (in frequency, amplitude, or motivational context) may be observed. Premature lumping must be avoided so that data are not lost irretrievably (Altmann, 1965), and if later analysis warrants, it is possible that data may be lumped (e.g., action patterns combined) into a more manageable number of categories. The recognition of individual elements permits later quantitative description and determination of relationships of the elements with each other (Russell, 1970).

\section{STUDIES IN CAPTIVITY}

Often the laboratory is the only place where for certain species behavioral observations such as those described above are possible; for a number of important reasons, the natural habitat of the animal may be an unsuitable locale for making detailed observations of social interaction - e.g., "who" did "what" to "whom," "how many times," and "when" (at what age and in what motivational context) (Bekoff, 1972). Some of these reasons are as follows: (1) inability to control social interaction; (2) inability to identify particular individuals; (3) interference by adults; and (4) the fact that young animals often do not emerge from the den or are not weaned until well after the critical period of social development has passed. Behavior observed in captivity may be of great importance in the natural environment, even though field workers have not yet described it (Chance, 1962). As stressed by Hopf (1970), hand-rearing is an indispensable prerequisite to controlling environmental influences on an animal; by being able to follow the development of particular identifiable individuals, questions pertaining to development can be answered (Birch, 1971; Lorenz, 1961).

In primates, Harlow and Harlow (1966) have 
TABLE 1

A developmental ethogram of motor action patterns in canids: category and code (after Bekoff, 1972)

I. NEONATAL (CONTACTUAL) - MAINTAINING SOCIAL PROXIMITY

$\begin{array}{ll}\text { Chin-rest } & \text { CR } \\ \text { Contactual-circling } & \text { CC } \\ \text { Face-lick } & \text { FL } \\ \text { Inguinal response } & \text { IR }\end{array}$

II. AGONISTIC - INCREASING SOCIAL DISTANCE

Offensive

Incomplete standing-over

Standing-over

ISO

SO

Back-arch

Defensive

Aggressive vocalization

AV

Distress vocalization

BA

Defensive gape

Submissive grin

DV

DG

SG

III. PASSIVE-SUBMISSIVE

${ }^{\text {a}}$ Rolling-over RO

${ }^{\text {a}}$ Face paw $\quad$ FP

IV. ACTIVE-SUBMISSIVE AND PLAY — DECREASING SOCIAL DISTANCE

Play-soliciting PS

Self-play SP

Rolling-over RO

Leap L

Leap-leap L-L

Tail-wag TW

Approach A

Tail-wag approach TWA

Exaggerated approach $\quad$ EA

Face-paw $\quad$ FP

V. PLAY-FIGHTING AND AGONISTIC

Head-shake Hsh

Hip-slam HS

Approach/withdrawal A/W

Scruff-bite intention SBI

Scruff-bite SB

Face-bite intention $\quad$ FBI

Face-bite $\quad$ FB

Face-bump FBp

Face-paw FP

General-body bite GB

(leg, flank, etc.)

a Observed in different motivational contexts.

reported that their laboratory animals show the same sequence of play behavior between 2 and 3 months of age as do feral monkeys, and in the Canidae, similar action patterns have been observed in both infant laboratory and nonlaboratory animals (e.g., Ludwig, 1965; Burrows, 1968; Silver and Silver, 1969; Mech,
1970; Fox, pers. commun.; Bekoff, pers. observ.). Klopfer (1972) has recently reported that observations of mother-infant pairs of lemurs in captivity were not different from behavior relations observed in the field. Wootton (1972) observed that the descriptions and interpretations of stickleback behavior observed in 
captivity (e.g., Tinbergen, 1951) are relevant to behavior observed in the wild. This last finding is particularly important, since the behavior of the stickleback is used as an example in many ethological models of motivation and behavior.

Furthermore, and perhaps more significant, is the possibility that behavioral development recorded during observations on captive animals can be correlated with the social organization and socio-ecological adaptations of the wild counterpart (Sheppard and Yoshida, 1971; Bekoff, 1972; Fox, in prep.). For example, it has been observed that captive red foxes (Fox, 1969), coyotes (Silver and Silver, 1969; Bekoff, 1972), and male Richardson's ground squirrels (Sheppard and Yoshida, 1971) display agonistic behavior in an aggressive context very early in life, and that these animals are known to disperse in natural populations (Burrows, 1968; Yeaton, 1972; Fox, in prep.). In contrast, wolves and beagles, for example, show more playful behavior than do coyotes or red foxes during the first 5 weeks of life, and this could be correlated with their packtype existence in natural populations, in which stable hierarchies and the maintenance of learned social affinities are essential for groupcoordinated behavior (Etkin, 1964; Haber, 1968; Bekoff, 1972).

Therefore, differences in social behavior in captivity could reflect differences in social structure in the wild. Whether the effects are circular, the differences in social structure being in part a consequence of the social environment in which the young develop, is a matter worthy of further study (Hinde, 1971a). McBride (1971) proposed that animal societies can be thought of as structures in space, with individuals as the building blocks, and the behavior of the animals providing its architecture. Suffice it to say, the observations noted above, all with supporting quantitative data, demonstrate the usefulness and relevance of ontogenetic studies carried out on captive subjects.

\section{VARIABLES IN DEVELOPMENTAL STUDIES}

There are many variables that must be taken into consideration and must be controlled during the course of any developmental study. Individual differences must be accounted for (e.g., Korner, 1971). When comparing different species, age-equivalence must be considered (Himwich, 1971). Bekoff and For: (1972) have discussed variables that affect development of the central nervous system, particularly in rodents, and it is not unlikely that many of them, if not all of them, affect the ontogeny of both brain and behavior in other mammals. These include handling (see Morton, 1968, for a review of this literature), cage size (Bell, Miller, and Ordy, 1971), birth mode (caesarian versus vaginal delivery - Meier, 1964; Meier and Garcia-Rodriguez, 1966; Grota, Denenberg, and Zarrow, 1966), conditions at birth (e.g., hypoxia, asphyxia - see Meier, 1971, for a review of this literature), and litter size (LaBarba and White, 1971). Poole (1966), studying the agressive play of polecats, stated that the size and agility of the animal depended on the number in the litter from which it came. Members of litters of two or three were often larger and more agile than those of seven or eight.

Structural and functional changes in the central nervous system must also be considered when studying the development of social interaction. Complex and dramatic changes may be taking place in the organization of the young animal's behavior, during a period when, to simple observation, the behavior does not seem to be changing very drastically (Lehrman and Rosenblatt, 1971). It has been demonstrated (Fox, 1971a; Bekoff, 1972) that changes in the quality of interaction between canids at approximately four weeks of age can be correlated with maturational changes in the nervous system. Increased control over thermo-regulation and increased locomotor ability seem to be responsible for the emergence of running and chase activity (see Bekoff, 1972).

\section{SOCIAL RELATIONS OF THE INFANT}

Mother-infant (e.g., Foss, 1961, 1963, 1965, 1969; Schönberner, 1965; Bowlby, 1969; Espmark, 1969, 1971; Fogden, 1971; Gould, 1971; Moltz, 1971b; Rosenblum, 1971; Klopfer, 1972), other adult-infant (e.g., Spencer-Booth, 1970), juvenile-infant, and infant-infant (e.g., Bekoff, 1972) relations must similarly be considered when observing behavioral development. There is increasing evidence that father-infant and 
other adult male-infant interactions are very im. portant in behavioral development of the young (e.g., Mitchell, 1969; Ransom and Ransom, 1971; Klopfer, 1972), as is the role of "aunts" (e.g., Hinde, 1965; Jolly, 1972). However, more data are sorely needed concerning this aspect of adult-infant interactions. The sex of the infant must also be considered (e.g., Jensen, Bobbitt, and Gordon, 1968).

Bekoff and Lockwood (pers. observ.) observed that a first-born beagle was handled much more and in a rougher manner than his littermates, and although in this litter all animals died in early infancy, it would seem that the effects of birth order must be considered; whether the mother is primiparous or multiparous (inexperienced or experienced) must also be a factor. Jay (1962, 1963) observed that multiparous langur mothers treated their infants differently than did primiparous mothers. The latter handled their infants less competently and startled them more frequently by sudden movements than did the former. Behavioral differences between 30-month-old offspring of experienced and inexperienced Rhesus mothers have been reported by Mitchell, Raymond, Ruppenthal, and Harlow (1966); and Thoman, Barnett, and Leiderman (1971) found differences in the feeding behavior of newborn humans to be a function of parity of the mother.

Time of birth might also be an important variable to take into account (Baldwin, 1969). In squirrel monkeys, infants born early in the birth season at first have few playmates other than stronger and behaviorally more sophisticated juveniles, while infants born late in the birth season are the weakest and the most helpless of their age class, since there are more infants with whom to interact (Hinde, 1971a). Group composition (age, sex) and size are very important variables that must be accounted for (e.g., Wolfheim, Jensen, and Bobbitt, 1970; Crook, 1970; Kummer, 1971).

It is clear that subtle variations in the social interactions of infants can markedly affect their behavioral development, and furthermore, there are reciprocal relations, in that a mother's (adult's) behavior will vary with the responsiveness of the infant and vice versa (Hinde, $1971 \mathrm{~b}$; Lehrman and Rosenblatt, 1971). Koepke and Pribham (1971) reported that the rate of development of play in cats may be related to the frequency of occurrence of an earlier behavior such as sucking, and differences in the development of sucking behavior may in turn be related to variations in infant-infant or mother-infant interactions, or both.

Van Lawick-Goodall (1971) presented data which suggested that mothers who were the most restrictive in curtailing their infants early in life were at the same time the most solicitous in other respects and also the most playful. It is also known that there are differences in the responses of mothers and other adults to male and female young (van Lawick-Goodall, 1968; Harlow, 1971; Harper, 1971), and that these variations might account for there being apparent sex differences in the early social development and interactions among primates (e.g., Latta, Hopf, and Ploog, 1967; Harlow, 1969). Sex differences were not observed in the infant canids observed by me (Bekoff, 1972), perhaps because the animals were hand-reared. To date, observations in the field have not clarified the above situation in the Canidae.

In conclusion, it would be important to investigate further whether there are differences in behavior toward male and female infants in a wide variety of animal species, and likewise to study the extent to which individual differences in temperament among "normal" mothers (e.g., permissiveness) affect the development of their infants. As yet, there are no such studies of the latter problem (Hinde, 1971a), which will be discussed below when the concept of behavioral neoteny is considered. Both field and laboratory studies suggest that further work is necessary in order to tease out and understand the complexities of the interactional experiences of a developing organism and to account for individual differences, since the gap in our knowledge of the normal behavior of mammals toward young is enormous, and theories of development of this relationship must take adequate account of the variety of rearing conditions (Spencer-Booth, 1970). Furthermore, there are limitations on cross-species generalizations (e.g., Seay, Schlottman, and Thorne, 1970; Eisenberg, 1972).

\section{A DEFINITION OF SOCIAL PLAY BEHAVIOR}

The development of play behavior has been studied in many species (for reviews, see Beach, 
1945; Piaget, 1951; Welker, 1961, 1971; Gilmore, 1966; Loizos, 1966, 1967; Ewer, 1968; Millar, 1968; Berlyne, 1969; Bekoff, 1972). Play with peers is one of the first non-motherdirected activities to appear early in life (Poirer, 1970) and is a voluntary activity (e.g., Huizinga, 1939; Herron and Sutton-Smith, 1971).

Satisfactory definitions of play are scarce. It is a phenomenon that is easier to describe then to explain (Darling, 1937). Lorenz (1956) has exclaimed: "Don't ask me to give a definition of play!" On the other hand, many theories about play have appeared in the literature and these have been reviewed by Gilmore (1966), Millar (1968), and Berlyne (1969). Subjective definitions and those that are contaminated by anthropomorphic and adultomorphic overtones - e.g., play being described as not real, not work, or not serious (Waelder, 1933; Chateau, 1954; Heckhausen, 1964; Stephenson, 1967) - do nothing more than muddle the issue. It is no wonder that Schlosberg (1947) and Berlyne (1969), twenty-two years later, concluded that psychology would do well to give up the category of play. Fortunately, neither psychologists, zoologists, nor philosophers have abandoned the ship. If mathematicians can calculate with imaginary numbers, investigators of behavioral ontogeny should be able to deal with the concept of play. Indeed, recent efforts using the observational, descriptive method have helped to unravel many of the complexities of the concept of play (e.g., Hutt and Hutt, 1970; Bekoff, 1972; Blurton Jones, 1972b; McGrew, 1972).

The basic problem seems to be in the terminology used to describe the phenomenon of play. This includes transference of concepts derived from human experience (Tinbergen, 1963) and adult interpretations that fail to take into account the "umwelt" of the child. Play indicates a form of behavior that is very serious and real for the infant and child (e.g., play therapy - Axline, 1969), and should be studied in this light.

Based on a comprehensive review of the literature and on many hours of observation of infant Canidae, I have offered an operational definition of play behavior as follows - one that is generally implied and infrequently stated in field notes and transcriptions of behavior observations. Social play is that behavior which is performed during social interactions in which there is a decrease in social distance between the interactants, and no evidence of social investigation or of agonistic (offensive or defensive) or passive-submissive behaviors on the part of the members of a dyad (triad, etc.), although these actions may occur as derived acts during play (Bekoff, 1972). In addition, there is a lability of the temporal sequence of action patterns, actions from various motivational contexts (e.g., sexual and agonistic) being combined (e.g., Ludwig, 1965; Loizos, 1966; Ewer, 1968) (Fig. 1). Infant contactual behaviors that have a passing biological basis (e.g., thermoregulation-discussed above) have been excluded (Bekoff, 1972), as have group feeding and sleeping. Play fighting can be detected by the intensity of the interaction, observation of the various actions which are performed simultaneously, and knowledge of the social development of the animals or species being observed. Establishment of an ethogram and categorization of the various motor action patterns is an essential prerequisite (see Table 1) for understanding behavioral ontogeny.

As mentioned above, the literature is replete with studies making the above basic assumption of what play is (or is not); moreover, viewing the concept of play as I have defined it makes it a manageable concept and avoids semantic difficulties. It is possible that there may have to be modifications to fit various species; however, at least in the family Canidae, play behavior can now be studied and manipulation experiments conducted, since the normal range of the frequency, amplitude, and components of temporal sequences of motor action patterns is known (Bekoff, 1972).

This author (and apparently those who are still actively engaged in studying play) does not agree with Welker (1971) that thorough studies of the developmental behavioral repertoire of various organisms have not justified the identification of play as a valid behavior class or a scientifically useful concept. Most studies to date have not actually entailed a highly detailed systematic design, such as establishing an ethogram, carefully following the development of social interaction from day to day during the early stages of socialization, or determining the normal range of behavior of the species under study (contra Tembrock, 


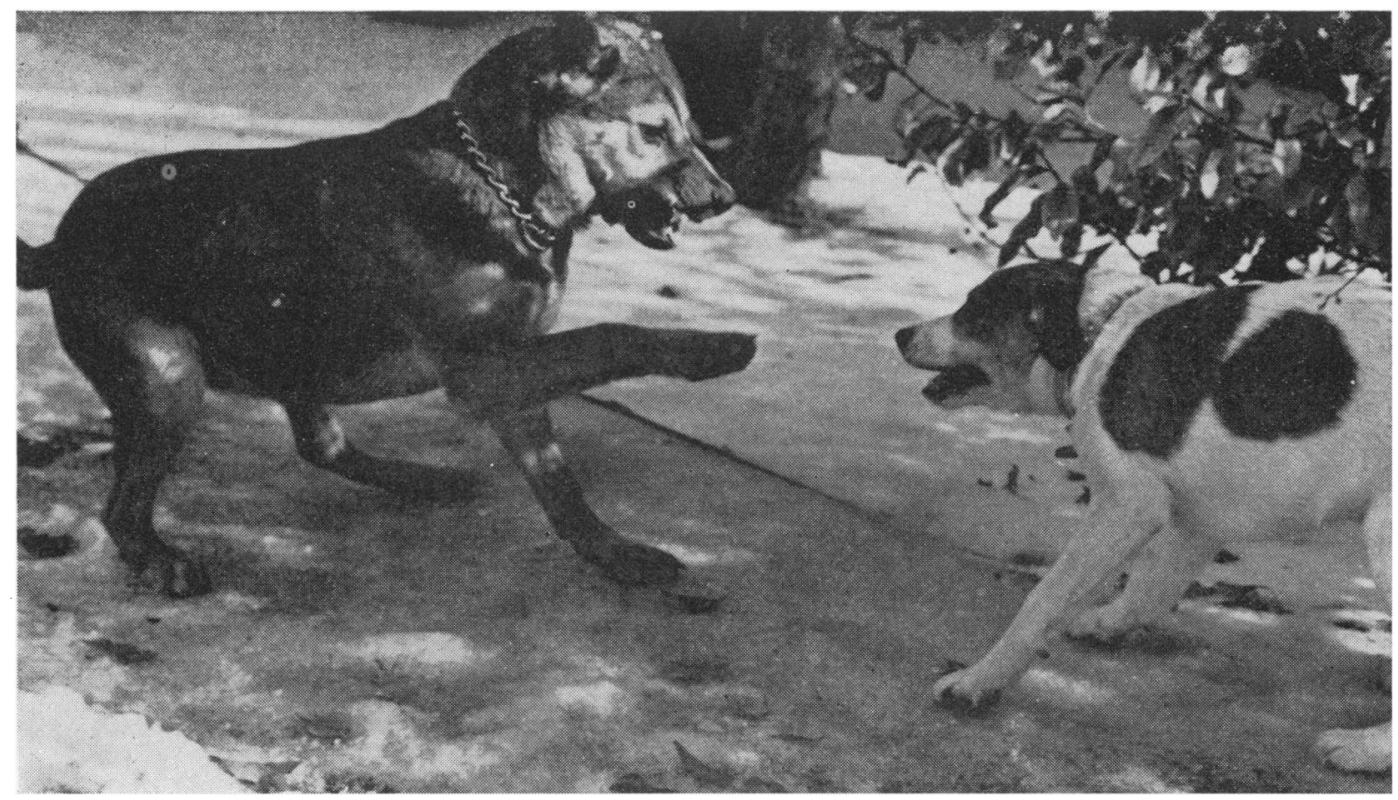

Fig. 1. An Example of Action Patterns from Various Motivational Contexts Being Combined During a Play Bout

The animal on the left is displaying an aggressive face (e.g., snarling with vertical retraction of the lips) and simultaneously performing a face-oriented pawing movement, in this case, a play-soliciting gesture. Subsequent interaction between this pair of animals was playful, and this provides a nice example of the fact that priority is almost invariably given to the play signal (e.g., Loizos, 1966).

1957; Bekoff, 1972; Blurton Jones, 1972b; McGrew, 1972).

While this article was in press, I discovered the following article concerning play behavior in primates: Doehinow, P. J., and N. Bishop. 1970. The development of motor skills and social relationship among primates through play. Minn. Symp. Child Psychol., 4:141-198. It concludes that "play is a major category of adaptive behavior that must be understood if we are to understand primate behavior." This strongly supports the position taken in the present paper.

\section{PLAY AND SOCIAL DEVELOPMENT}

Although there has been a lack of definition of the phenomenon of play behavior, there certainly has been no dearth of studies relating play to social development (see Sleet, 1971, for an exhaustive bibliography). There has been a unanimous conclusion that the development of social behavior is intimately related to the ontogeny of social play. Most authors have accepted the existence of play in a phenomenological sense (e.g., Mason, 1965), and Muller-Schwarze (1971) has stressed that the amount of time and paper spent on speculations about motor play in immature animals is in inverse proportion to the amount of facts available on the question. In addition, Poirer (1970) has added that detailed studies of the role of play in the socialization process are lacking.

Harlow and Harlow (1961) listed five stages in the development of play behavior in Rhesus monkeys and later wrote that interactive play is an essential element in the development of affectional behavior toward age-mates (Harlow and Harlow, 1966). Harlow and Suomi (1971), studying social recovery by monkeys reared in isolation, stated that the most critical and valid measures of social recovery were those of social contact and play. The increasingly complex processes of play provide the means and motives for the development of the peer system (Harlow, 1971). This appears to be true for a wide range of animals (Bekoff, 1972; Blurton Jones, 1972b).

The rationale behind play therapy (Axline, 1969) and the infantile dynamics theories of 
play (which take into account the "umwelt" of the developing organism-e.g., Gulick, 1920; Lewin, 1933; Buytendijk, 1933; Piaget, 1951) emphasize the point that play and social development are intimately tied. Play with peers is so important that Harlow (1969) and Tisza, Hurwitz, and Angoff (1970), studying infant Rhesus monkeys and hospitalized children respectively, were able to demonstrate that interaction with peers can override the effects of separation from the mother and make it a less traumatic experience. Causey (1956, cited by Scott and Bronson, 1964) observed that in infant dogs a littermate was more effective than the mother in reducing vocalizations in a strange environment. Harlow (1969) referred to the above phenomena as a biological safety valve. Finally, Kagan and Beach (1953) reared infant male rats with mature females, and these males failed to develop normal sexual responses. They concluded that a pattern of play activity associated with females had conditioned the young so as to bar recognition of the females as sex objects.

Suffice it to say, data collected on a variety of animals, both in the field and in the laboratory, have conclusively demonstrated that normal behavioral development depends on there being adequate infant-infant interaction. Systematic observations on a wider phyletic range of species is sorely needed. Fortunately, such studies are beginning to appear in the literature (e.g., Farentinos, 1971; Steiner, 1971). It must be stressed once again that mother (adult)-infant interactions are not totally indispensable, and when the mother (or another adult) is present, she plays a role in the behavorial ontogeny of her offspring. Progeny from different ranking animals may show differential development of social behavior (Kawai, 1958; van LawickGoodall, 1968; Harper, 1970). Therefore, as already stated, developmental studies must account for the extent to which adults interact with particular infants (Hinde, 1971a; SpencerBooth, 1970).

\section{THE FUNCTIONS AND CONSEQUENCES OF PLAY}

Since so many animals appear to spend a lot of time and energy at play while young, it is necessary to consider the possible functions of play. Mason (1960) wrote that normal commu- nicative skills are acquired during early social interaction, and the marked impairment in social ability exhibited by socially deprived monkeys may be due, in part, to a lack of opportunity to develop communicative skills which facilitate social interaction. This also appears to be true in a variety of organisms such as fallow deer (Gilbert, 1968) and canids (Fox, 1971a), and can also account for the findings of Kagan and Beach (1953) noted above. The ability of an animal to "understand" intraspecific communicative signals depends upon social experience and social conditioning - e.g., the development of expectancies and learning of the context (behavioral set + mood) in which various actions are performed - and this capacity is acquired through the totality of social experience of the infant. This will be discussed in depth when the concept of metacommunication (after Bateson, 1955) is presented and re-evaluated.

Play is almost always observed when the more immediate physiological drives of the infant (or adult) have been satisfied. In accord with the hypothesis that play is not a primary activity (Meyer-Holzapfel, 1956a,b), Hafez, Schein, and Ewbank (1969) have observed that well-fed calves play more often than sick or poorly fed ones, and Farentinos (1971) added further support with his observations that play occurred after more immediate drives (e.g., hunger and sex) had been satisfied, and that territorial male Steller sea lions (in active territorial defense) were never observed in any behavior that could be labeled as play. Espmark (1969) also observed that play in roe deer did not occur unless the motivation to perform some innate behavior to satisfy an immediate physiological need had ceased. It has been proposed quite frequently that the reason why play is observed more in infants than in adults is because infants are not responsible for satisfying the various physiological requirements of development (Millar, 1968). If play activities are inhibited or prevented from developing because of the occurrence of certain environmental or physiological conditions, the behavioral repertoire may become severely distorted (Welker, 1971).

Groos (1898) emphasized that young animals play in order to pre-exercise instincts in preparation for later life. He failed to recognize, however, the orderly progression of various de- 
velopmental stages of play and the effect of each stage on each subseqent stage (Harlow, 1971). Poole (1966), however, observed that in polecats the patterns involved in aggressive behavior are stereotyped and unmodified by experience; and Fox (1969) demonstrated that infant coyotes, when given their first prey-killing session with live rats, will go through a ritualized prey-killing sequence without having ever played (with conspecifics or dead rats). These observations do not support Groos' theory. Welker (1971), in his detailed review of the literature, also concluded that the practice function of play has not been verified.

Leyhausen (1965) suggested that, through play, cats enrich the scope of their experience and the range of their skills in many and diverse ways. They create play situations, and in so doing, they learn more than ever would be possible if they were limited exclusively to instinctive movements along the "one-way street" of an unalterable sequence rigidly confined to biologically relevant situations (Leyhausen, 1965). Barnett (1970) wrote that the function of play in development is learning to learn (deutero-learning), and Eisenberg (1966) noted that play appeared to aid in the functional integration of innate patterns. The concept of the modification of motor action patterns through social experience and social conditioning requires further elaboration, and will be discussed in detail below.

Brownlee (1954) studied play in domestic cattle, and offered a physiological explanation for the function of play. He suggested that play in cattle (and in other organisms) is a single instinct, with its own drive, releasers, emotions, consummatory phase, and goal. Cattle derive physiological benefits from playing - e.g., increased blood supply to the muscles involved and increased muscle tone. There is much evidence that the use of various organs (e.g., the eyes) is essential for structural maturation and the development of functional integrity (see Bekoff and Fox, 1972), and Brownlee's physiological explanation for the function of play appears to be valid. Whether or not there is a "play drive," as he also suggested, is disputable (see below).

In canids, social play seems to be important in learning to control the intensity of the bite (Fig. 2), and in facilitating the formation and continued maintenance of social organization and social affinities within a group (Etkin, 1964; Haber, 1968; Bekoff, 1972). Estes and Goddard (1967) observed playful "pep-rallies" preceding a hunt in African wild dogs. Learning and expression of certain social gestures and postures during play in young animals may serve subsequently to inhibit aggression and thus make possible the formation of stable group hierarchies (Jay, 1965). Harlow (1971) similarly concluded that during free social play, social roles develop and the rules of social intercourse are shaped and the control of immediate demands and aggression is established; and Scott (1968) suggested that play may contribute to the development of group-coordinated and allelomimetic behavior. Recently, Wickler (1970) has written that comparative examinations of various socially-living vertebrates have shown that certain regular behavior elements serve for stabilization of their societies and that these elements are not new, but are derived from their behavior repertory (e.g., definition of play given above).

Extensive data collected in this laboratory provide evidence that the more social Canidae (e.g., beagles and wolves) engage in more. playful interactions earlier in life than the more solitary species such as the red fox and coyote (Fox and Clark, 1971; Bekoff, 1972). The former, unlike the latter animals, in which dominance hierarchies are formed before the emergence of play (most frequently by a severe dominance fight between 25-30 days of age - Fox and Clark, 1971; Bekoff, 1972), form their social hierarchies through playful interactions. As pointed out in the beginning of this review, red foxes and coyotes are solitary and semisolitary species respectively (Burrows, 1968; Rue, 1969; Fox, 1972), and it is possible that this early ontogeny of aggressive behavior (observed both in captivity and in the wild) is responsible for later dispersal and a virtual absence of group coordinated behavior (e.g., hunting) as adults (e.g., Burrows, 1968; Hinde, 1971a; Fox, 1972).

\section{IS THERE A "PLAY DRIVE?"}

The animal literature concerning play behavior is replete with unsubstantiated allusions to the existence of a "play drive." Specifically, 


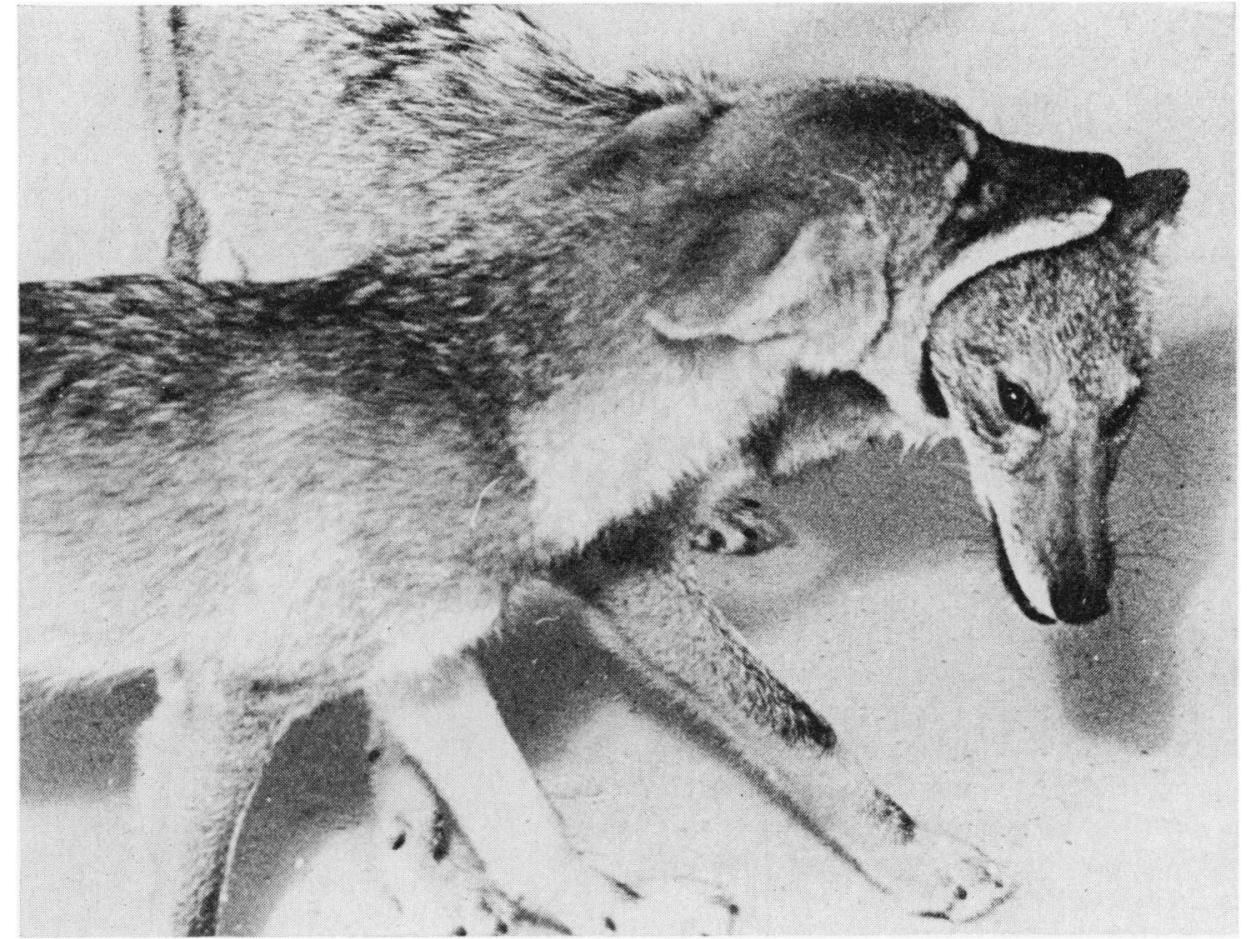

Fig. 2. An Inhibited Bite During Playful Social Interaction of Two Four-Month-Old CoYoTES

The dominance hierarchy has already been established. Note that the ears are pressed back. (From Bekoff, 1972.)

it is implied that an animal deprived of play activities will show an increase over the normal amount of play behavior when subsequently allowed to perform such motor action patterns. Lorenz's psychohydraulic model (1950) would be applicable in this line of reasoning. Hinde (1960), Beer (1968), and Henderson (1972), have concluded, however, that energy models of motivation based upon the existence of unsubstantiated physiological processes (such as the building up of energy in a psychic reservoir) should not be used in formulating or supporting behavioral themes. At this time, it would be unwise to use an unsupported model of behavioral motivation and drive to explain such a controversial phenomenon as play. Furthermore, investigators have not adequately separated the drive for general motor activity from the drive to play, if, in fact, either does exist.

Lore (1968) has reviewed the literature concerning the activity-drive hypothesis. He con- cluded that there is little evidence that could justify the postulation of an autonomous activity drive. He wrote that the critical variable seems to be experiential deprivation, rather than activity deprivation per se. This suggestion fits in nicely with the experimental evidence offered by Melzack (1952), Thompson and Heron (1954), Melzack and Scott (1957), and Melzack and Burns (1965), namely, that experientially deprived dogs of many different breeds are hyperactive and extremely emotional upon release from isolation. Fuller (1967) has reviewed the isolation-emergence syndrome.

It is therefore not appropriate at the moment to speak of the existence of a specific play drive. The methods that would have to be used to determine its presence (or absence) would not only deprive a developing organism of play experience, but of all types of social interaction, and the isolation syndrome is very complex (Fox, 1971a). The two formal attempts to investigate the possibility of the existence of a play 
drive have produced divergent results. MullerSchwarze (1968), studying deer, found no evidence for the postulation of a play drive in them, while Chepko (1971), observing infant goats, found that deprivation of play led to an increase above the norm in subsequent play behavior. Muller-Schwarze (1968), however, did not control for the effects of learning (Chepko, 1971); and Chepko (1971) did not control for the effects of punishment. Bekoff and King (unpubl.) observed that in infant beagles and coyotes, after 24 hours of social isolation from their littermates, there was greater than usual general activity during a subsequent period of social interaction with a peer. Since two animals were being observed at the same time, this increase in activity led to an increased interaction and to more play, as well as more aggressive behavior. The frequencies of all types of behavior were elevated.

In conclusion, the causes for restlessness after social deprivation are many. It appears to be virtually impossible to verify experimentally the existence of a play drive, because methodological insufficiencies do not allow an experimental manipulation that deprives an organism solely of play experience (Glickman and Sroges, 1966). Along these lines, the hypotheses of Harlow (e.g., Harlow and Harlow, 1966) and others, who state that socially deprived animals are deficient in performing adult behaviors because they were deprived of play experience as youngsters, need revision [see Meier (1965) and Ewer (1968, p. 323) for further discussion of this point]. The effects that are produced by using isolation techniques must be interpreted in terms of the methodological deficiencies.

A very recent analysis of data collected by this author has suggested the existence of a "play drive" in the infant canids observed. The methodology did not involve deprivation procedures (social isolation or experimenter intervention), but rather analyses of temporal sequences of behavior and qualitative and quantitative differences in behavior and activity, between the members of the dyads observed.

Briefly, it has been demonstrated that self-directed play (e.g., tail-chasing) may serve as a substitute for social play, when the possibility for social play is blocked - e.g., when one animal is intolerant of the proximity of its partner (coyotes), or when one animal is either totally withdrawn (inactive) (beagles and wolves) or sub- missive (coyote-beagle hybrids and wolf-malemute hybrids). In those instances when playsoliciting by one animal did not result in any playful interaction (decrease in social distance), self-directed play appeared to be a redirected form of social play, indicating the possible existence of a "play drive." The soliciting animal had "metacommunicated" its intention and mood, and when its expectation was not met, selfdirected play resulted. That this self-directed play was not just the result of a general drive for motor activity (e.g., Meyer-Holzapfel, 1956a,b) is indicated by the fact that it was preceded by a play-soliciting gesture, indicating "desire" for a specific type of motor activity-social play.

SOCIAL EXPERIENCE AND THE DEVELOPMENT OF COMMUNICATIVE AND METACOMMUNICATIVE

\section{SKILLS}

During early social interaction, communicative skills are developed (e.g., Mason, 1960; Miller, Caul, and Mirsky, 1967; Jolly, 1972). One very important ability that must be acquired early in life is that of being able to differentiate playful from non-playful interactions. Bateson (1955) observed primates playing and concluded that "play could only occur if the participant organisms were capable of some degree of metacommunication, that is, of exchanging signals which could carry the message that "this is play'." This message is conveyed by vocalizations, facial expression, and bodily gestures (e.g., style of approach) in primates (Van Hooff, 1962, 1967; Altmann, 1962, 1965, 1967; Schaller, 1963; Hall, 1967; Ploog, 1967, 1969) as it is in the Canidae (Darwin, 1872; Rheingold, 1963; Ludwig, 1965; Fox, 1970a; Bekoff, 1972). Struhsaker (1967) has recorded a play call in vervet monkeys which may enhance the play bond between individuals and thus facilitate the occurrence of future play encounters. Van Hooff (1972) discussed human laughter and smiling as being metacommunicative signals.

Metacommunication involves communication about communication, and in metacommunication there is contextual dependency (Cullen, 1972). Primates include in their behavioral repertoire a set of social messages that serve to affect the way in which other social messages are interpreted (Altmann, 1962). Kummer (1971) wrote that primates use their vocalizations, ges- 
tures, and facial expressions to inform recipients of what could be called the present mood of the actor, about what he is likely to do next. Apart from expressing his own intentions, a monkey can also influence the intentions and moods of his fellows. In this way, animals are able to distinguish between playful and serious [sic] encounters (Altmann, 1967). The same is true for the Canidae (Bekoff, 1972), ground squirrels (Steiner, 1971), and cats (Loizos, 1966). Thus, preceding and accompanying play encounters, these animals will perform certain movements - e.g., primates: gamboling, and looking through their legs at their playmates (Altmann, 1962; Schaller, 1963; Van Hooff, 1967; Poirer, 1970); canids: play-bow or playdance (Fox, 1970a; Bekoff, 1972). These movements signal to the other members of the play group that any aggressive behavior in the play situation will not be real aggression. Even though jaw musculature and dentition are well developed in adults, inhibited biting is observed. It is possible for metacommunication to break down, when, for example, the intensity of interaction increases (e.g., loss of bite inhibition - Fox, 1971b; Bekoff, pers. observ.).

The development of metacommunicative abilities is intimately related to the dynamics of the social ontogeny of a developing organism. Basic communicative skills must be acquired for normal behavioral development and eventual competent performance during adult social interactions. The concept of metacommunication must be thoroughly re-analyzed in this light since, as Altmann (1967) has correctly stated, the components underlying metacommunication are acquired during early life through social interaction. Since the developmental studies that have been carried out on the Canidae over the past years have involved careful control of social interaction, and life histories can be accounted for (see Fox, 1971a; Bekoff, 1972), an attempt will be made to discuss and understand metacommunication in proper perspective as a developmental phenomenon.

\section{THE DEVELOPMENT OF BEHAVIOR SEQUENCES}

Fox and Clark (1971) presented an epigenetic paradigm for the postnatal ontogeny of behavior patterns as follows: (1) maturation: the gradual emergence of a given action pattern or "unit" of a more complex sequence of behavior; (2) generalization: the action pattern is observed in a variety of motivational contexts; (3) individuation: the action pattern is observed in a more specific motivational context; (4) integration: the action pattern becomes integrated with other action patterns and is consequently incorporated into a relatively predictable sequence of behavior; and (5) socialization: the elicitation of the action pattern is to some extent determined by the relationship of one animal to another (e.g., in terms of dominance and subordination). The contribution of experience and inhibition of responses "inappropriate" to the situation are important in the ontogeny of temporal sequences of motor action patterns and their content. Therefore, as mentioned above, it is misleading to analyze a developing, inexperienced organism in terms of characteristics that are only applicable to experienced organisms (e.g., Welker, 1971; Bekoff, 1972).

Fox (1971c) has recently stressed the point that organisms are born with a set of species characteristic behavior patterns, which can be modified to varying degrees as a result of social experience and learning (see Fig. 3-2 in Fox, 1968). Components of ongoing behavioral sequences are synthesized through a series of transactional experiences (Kaufman, 1960); and genetic, ontogenetic, experiential, and socioenvironmental variables are involved (Fox, 1971c). It has recently been demonstrated that species-characteristic action patterns do play a role in the various developmental sequences of social interaction observed in canids (Bekoff, 1972). Mason (1971) similarly viewed the development of an individual organism as the outcome of the interaction between genotypic tendencies (e.g., the performance of certain motor action patterns) and specific circumstances. Therefore, it is essential to view the contributions of heredity and environment as being fused at all stages of ontogenesis (Schneirla, 1966; Fox, 1970b). Maturation and growth of the central nervous system, as well as normal behavioral ontogeny, require both proper genetic endowment and appropriate environmental stimulation, and are neither entirely "environment-expectant" nor "environmentdependent” (Bekoff and Fox, 1972). Changes 
in either heredity or environment can affect the way in which a developing organism perceives and reacts to its environment (Fox, 1970b). [The reader is referred to Hebb (1953); Lehrman (1953, 1970); and Lorenz (1965), for discussions in depth of this controversial developmental issue.]

\section{BEHAVIORAL NEOTENY}

Incorporated in this whole notion of the development of behavioral sequences, which stresses the importance of social interaction for the developing organism, is the concept of behavioral neoteny. [See Montagu (1972) for a discussion of fetalization, neoteny, and pedomorphosis from an anatomical-morphological point of view.] The concept of neoteny, which takes into consideration the prolonged period of dependency on the mother (or other adults) and the corresponding delayed personal responsibility of the infant for satisfaction of primary needs, can be used in the explanation of the phylogeny and ontogeny of behavior (Mason, 1968). Fiske (1875; cited by Mirsky, 1968) regarded the prolonged period of infancy as a "period of plasticity . . . a door through which the capacity for progress can enter .... (to) modify . . . inherited tendencies." Levy (1943) used the term "infantilization" to refer to activities and communications by which a child (or other person) is encouraged to remain (or become) more dependent on another. [Jonas and Klein (1970) have recently discussed the concept of infantilization in man in terms of a disease-model of evolution.] Therefore, prolonged infancy in "higher" vertebrates, and an increased time in which to develop the necessary communicative and metacommunicative skills necessary for normal social development, may involve reciprocal interaction between mother (or other adults) and young, in that the behavior of one can alter the behavior of the other and affect what occurs during early life. Individual differences among infants involving the degree of persistence of infantile needs, and individual differences among mothers (e.g., in permissiveness or restrictiveness) must be accounted for (as discussed above), in that the period of dependency may be correspondingly shortened or lengthened.

As we ascend the phylogenetic tree, there ap- pears to be a correspondingly longer period of infancy, and more time for social interaction and play (Hebb, 1949; Tobach and Schneirla, 1968). The adaptive or survival value of prolonged infancy is related to a "greater need for learning" rather than a "greater period in which to learn" (Mason, 1968). This need is related to the relative paucity of fixed reflexlike patterns of behavior and a larger set of behavioral potentialities than was possessed by phyletic predecessors (Mason, 1968). Animals with an inherited repertory of perceptions and motor coordinations do not need this opportunity, being already provided with such neural organization (Nissen, 1951).

It is clear that the "need" for social interaction and the availability of a prolonged period in which to interact are related. The paradox that Herron and Sutton-Smith (1971) discuss - namely, that play is usually thought to be non-productive, while at the same time it has been declared to increase in extent as one ascends the phylogenetic scale - is really no paradox at all, since (1) play is a very productive activity, in so far as it allows the developing organism to realize behavioral potentialities essential for normal behavioral development and adult life; (2) play exposes the animal to conspecifics and inanimate objects in its environment (like exploratory behavior), and therefore experience about the socio-environmental milieu may be gained; and (3) the channeling of innate motor action patterns into adaptive sequences of behavior is mandatory for organisms in which there is a relative paucity of innately determined sequences (e.g., Fox, 1971c; Mason, 1971; Fig. 3). Play is an essential function of childhood, and the "open-system" of the developing organism may provide the door for cultural influences (e.g., Huizinga, 1939; Itard, 1962; Lowenfeld, 1967; Kummer, 1971).

\section{THE COMPONENTS OF METACOMMUNICATION}

A discussion of the development of the behavioral components underlying metacommunication can now be undertaken in light of the above. Since communication implies that the behavior of one animal is changed upon its perception of a signal from another animal (Marler, 1967), play-intention signals are certainly communicative, and also metacommu- 
THE DEVELOPMENT OF SOCIAL INTERACTION

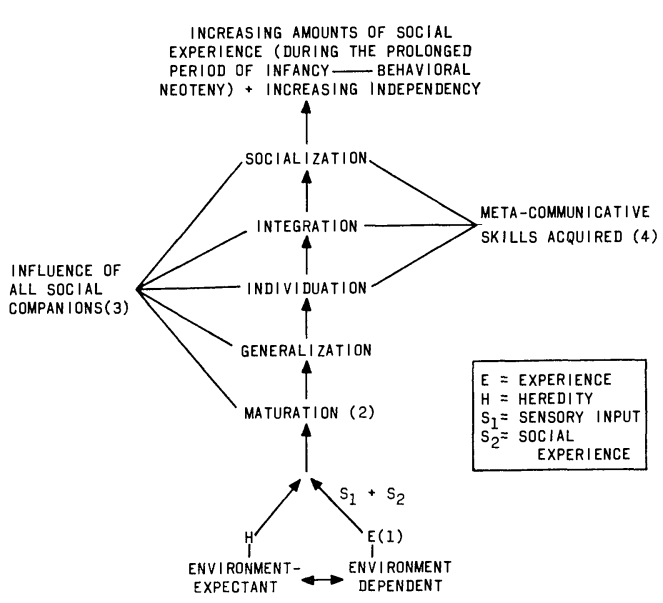

Fig. 3. The Relationship Between Heredity, Environment, the Development of Temporal SeQUENCES OF BEHAVIOR WITH SOCIAL EXPERIENCE, Behavioral Neoteny, and Metacommunication

See text for explanation. Notes: (1) see Fox, 1968; Bekoff and Fox, 1972. (2) Scheme for the postnatal ontogeny of temporal sequences of motor action patterns (Fox and Clark, 1971). (3) See text and Fox, 1968; Bekoff and Fox, 1972. (4) Ability to communicate mood and identify behavior sets during social interactions.

nicative, in that they invariably elicit a playful response on the part of the recipient, detectable in terms of a change in body position, orientation, and spatial relationship (decreased social distance). Causation may be implied by the behavior that is elicited (Blurton Jones, 1968).

As the organism develops in terms of central nervous system maturation, skeletal-muscular growth, and increased amounts of social experience, innate motor action patterns are channeled into situation-specific behaviors (Fox, 1971c). The responsiveness to conspecific signals may improve with experience, in that the animal may learn through socialization (social conditioning) to identify certain behavior sets and also to express and recognize mood and readiness to play. Signal context + expectancy + mood (or readiness), which are expressed, perceived, and shared, are the underlying components of metacommunication (Bekoff, 1972). There is an intimate reciprocal relationship between sender and receiver, and this may account for the fact that animals reared in similar social environments display preferences for one another (e.g., Pratt and Sackett, 1967; Sackett,
1970). An isolation-reared monkey may come to prefer a like-reared monkey on the basis of behaviors which that monkey does not perform (Sackett, 1970), because isolated animals have not developed metacommunicative skills. A non-isolated animal may become an aversive stimulus to such an isolated one because of dissimilarities in behavior, facial expression, and body posture (Sackett, 1970). A similar mechanism might also account for the findings of Leach (1972), namely, that children who had difficulty in separating themselves from their mothers had reduced, unsatisfactory interactions with peers.

Gilbert (1968), while studying the behavior of fallow deer, observed that the most striking effect of hand-rearing (without social experience) is the cleavage of the social bond between the fawn and its own kind. The elements that are essential for herd organization - the cohesion of individuals and the awareness of slight changes in mood by exchange of signals - have been disintegrated. Finally, MacNamara (1972) wrote that infants learn language by first determining, independently of language, the meaning which a speaker intends to convey to them, and uses meaning as a cue to language. Although metacommunicative signals might be species-specific, it seems highly likely that additional comparative ontogenetic studies will demonstrate their existence within a wide phyletic range. Ramsay's statement (1969) that metacommunicative messages are rare in animals is premature.

Clarity of the message is an essential prerequisite, and in line with Tinbergen's (1951) notion that a "social releaser" must be simple, conspicuous, and specific and Morris's (1957) concept of "typical intensity," play-intention signals must be unambiguous and not confused with other behavioral signals, since they specify what type of behavior is to follow. Morris (1957) stressed that where a response is acting as an agent of social communication, it is advantageous for it to possess a certain constancy of form in order to eliminate signal ambiguity. This is particularly important in the case of play signals, since it is essential that the mood of the ongoing interaction be maintained in a manner appropriate to the initial stimulus (e.g., a play invitation).

In canids, a particular motor action pattern, 
the "play-bow" (Fig. 4; Fox, 1970a; Bekoff, 1972) - a crouching of the fore-part of the body with elevation of the hind-end - has been observed to be a situation-specific, social releaser for play. Darwin (1872) first observed this and wrote that it occurred when the dog is in a "humble and affectionate state of mind." In the dog and the wolf this action is also seen during the greeting of a familiar person (Schassburger, 1968; Fox and Bekoff, personal observations). In coyotes, the play-bow develops into a "play-dance" (Fox, 1970a). The message that is conveyed by this "appetitive" action results in a decrease in social distance and playful, nonaggressive interaction. Play-soliciting sequences often incorporate exaggerated approaches, approach/withdrawals (to initiate chase), facepawing, and infrequently face-licking, with the soliciting animal wearing a "play-face," as described by Fox (1970a) in canids and by van Hooff $(1962,1967)$ in primates.

Steiner (1971) observed play-soliciting signals in ground squirrels, and interpreted them as being intention movements (movements indicating "intent"), attention-getting devices, or both. Signals which draw the attention of the receiver (e.g., "Look herel") are described as deictic (Lyons, 1972). Very often in dogs, a play-bow is accompanied by a loud bark (Fig. 4), and in primates an audible "play-pant" has been recorded (Van Hooff, 1967). Poirer (1970) has accordingly observed that, in langurs, behavior commonly associated with play initiation seemed to attract the attention of prospective playmates.

\section{RITUALIZATION AND METACOMMUNICATION}

Cullen (1966) wrote that the process of ritualization results in increasing the conspicuousness of signals with a concomitant decrease in ambiguity. Ploog (1970) has viewed ritualization as involving the adaptive canalization of expressive behavior. As play in canids develops, it becomes species-typical and more ritualized (an ontogenetic ritualization). Indeed, the characteristics listed by Morris (1966), referring to changes that occur during the evolution of ritualized behavior, closely parallel the characteristics of play behavior as listed by Loizos $(1966,1967)$ and by Ewer (1968) in their respective reviews (e.g., reordering of sequences, repetition, exaggeration, and fragmentation of movements). Unfortunately, the process of ritualization has not been specifically studied in the case of animal play (Thorpe, 1966).

During a play-bout, there is continuous feedback from one participant to another, and the ability to control aggressive behavior and react appropriately to the mood of the ongoing inter.

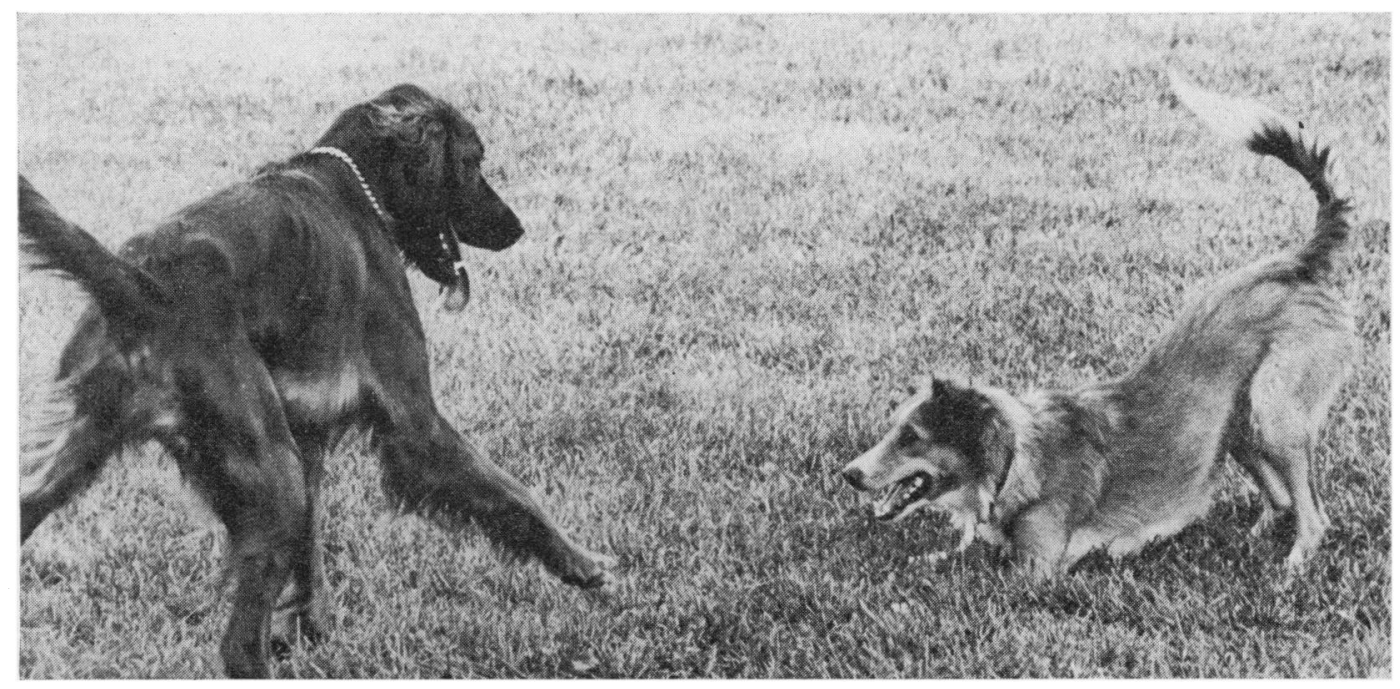

Fig. 4. A "Play-Bow," Accompanied by a Bark

This social releaser for play is an intention movement and a bark, an attention-getting device (from Bekoff, 1972). 
action would benefit from increased ritualization and greater amounts of social experience. The function of a signal and the information content are largely determined by the response of the recipient (Maurus and Ploog, 1971). It is therefore necessary for the participants to be aware of strategies and behavior sets, and likewise for the investigator to study them (Kummer, 1971). McBride (1971) wrote that during a social encounter each animal "assembles" the next block of responses to be emitted by using information from the whole context of the interaction, but more specifically in the form of feedback from the behavior of the interactant.

The communicative "output" of one animal is not necessarily identical to the "input" that the recipient registers (e.g., Vine, 1970), and the inefficiency of transmission can be reduced by either animal (Vine, 1970). It can be further reduced by the ritualization of the particular components of the message - e.g., facial expressions, gestures, body postures, and vocalizations. In canids and in primates, the ritualization of situation-specific signals has been instrumental in providing a foundation for the ability to develop, and to use effectively, signals that carry a message which conveys a mood, and that indicate what is to follow in time (e.g., play). The appetitive action patterns involved in play invitation have been reduced to their simplest components with a concomitant decrease in ambiguity. Accordingly, the requirement for playful interaction, both for developing organisms and for the maintenance of adult social organization, can be more effectively realized.

\section{SUMMARY AND CONCLUSION}

More systematic studies of the development of social interaction and of communicative skills are sorely needed. Developmental ethograms and sociograms must be established and action patterns categorized in terms of the motivational context in which they appear. Subtle intervening variables must be accounted for and teased out in order to achieve a clearer picture of the dynamics of behavioral ontogeny. The developmental, comparative approach provides a powerful tool for behavioral research; and studies conducted on some captive animals appear to be quite relevant, and their results intimately related to behavior and social organization observed in their wild counterparts.

The concept of behavioral neoteny is related to the whole of social ontogeny, in that animals that are born with a paucity of genetically fixed behavioral sequences require a period in which inborn motor action patterns become integrated and canalized into situation-specific contexts. Future studies should concentrate on investigating the process by which adaptive chains of temporal sequences of motor action patterns are assembled, as well as determining the "adaptive capacities" and potentials of the developing organism.

Social interaction, consisting of both agonistic and playful encounters, is essential for the normal behavioral development of an infant mammal, and through this social experience communicative and metacommunicative skills are acquired. Play is a valid class of behavior and a useful developmental concept. The process of ritualization has played an important role in the development and elaboration of specific metacommunicative signals - those conveying messages of mood and intent.

\section{ACKNOWLEDGEMENTS}

I would like to thank Michael W. Fox for critically reading this manuscript and for the many helpful suggestions that he has offered over the past years. The author's work was supported in part by PHS Training Grant GM-1900 and PHS Grant ES-00139, through the Center for the Biology of Natural Systems, Washington University.

\section{LIST OF LITERATURE}

AltmanN, S. 1962. Social behavior of anthropoid apes: Analysis of recept concepts. In E. L. Bliss (ed.), Roots of Behavior, p. 277-285. Hafner Publ. Co., New York.

1965. Sociobiology of rhesus monkeys, II: Stochastics of social communication. J. Theoret. Biol., 8: 490-522.
- 1967. The structure of primate social communication. In S. A. Altmann (ed.), Social Communication Among Primates, p. 325-362. Univ. of Chicago Press, Chicago.

Axulne, V. M. 1969. Play Therapy. Ballantine Books, New York.

BaLdwin, J. O. 1969. The ontogeny of social be- 
havior of squirrel monkeys (Saimiri sciureus) in a semi-natural environment. Folia Primatol., 11: 35-79.

BARNETT, S. A. 1970. Instinct and Intelligence. Pelican Books, London.

Bateson, G. 1955. A theory of play and fantasy. Psychiat. Res. Rep. A., 2: 39-51.

BEACH, F. A. 1945. Current concepts of play. Am. Natur., 79: 523-541.

BEER, C. G. 1968. Ethology on the couch. In J. H. Masserman (ed.), Animal and Human, p. 198-213. Grune and Stratton, New York.

BEKoFf, M. 1972. An ethological study of the development of social interaction in the genus Canis: A dyadic analysis. Ph.D. thesis, Washington University, St. Louis.

Bekoff, M., and M. W. Fox. 1972. Postnatal neural ontogeny: Environment-dependent and/ or environment-expectant? Develop. Psychobiol., in press.

Bell, R. W., C. E. Miller, and J. M. Ordy. 1971. Effects of population density and living space upon neuroanatomy, neurochemistry, and behavior in the $\mathrm{C}_{57} \mathrm{Bl} / 10$ mouse. J. Comp. Physiol. Psychol., 75: 258-263.

BerLyne, D. E. 1969. Laughter, humor, and play. In G. Lindzey and E. Aronson (eds.), The Handbook of Social Psychology, Vol. 3, p. 795949. Addison-Wesley, Mass.

Вirch, H. G. 1971. Levels, categories, and methodological assumptions in the study of behavioral development. In E. Tobach, L. R. Aronson, and E. Shaw (eds.), The Biopsychology of Development, p. 503-514. Academic Press, New York.

BLurton Jones, N. G. 1968. Observations and experiments on the causation of threat displays of the great tit (Parus major). Anim. Behav. Mono., 1: 75-158.

- 1972a. Characteristics of ethological studies of human behavior. In N. G. Blurton Jones (ed.), Ethological Studies of Child Behaviour, p. 3-33. Cambridge Univ. Press, Cambridge. - (ed.). 1972b. Ethological Studies of Child Behaviour. Cambridge Univ. Press, Cambridge.

Bowlby, J. 1969. Attachment and Loss. Vol. 1: Attachment. Basic Books, New York.

Brownlee, A. 1954. Play in domestic cattle in Britain: An analysis of its nature. Brit. Vet. J., 110: 48-68.

Burrows, R. 1968. Wild Fox. Taplinger Publ. Co., New York.

BUYTENDIJK, F. J. J. 1933. Wesen und Sinn des Spieles: Das Spielen des Menschen und der Tiere als Erscheinungsform der Liebenstriebe. Wolff, Berlin.
CAusey, A. 1956. A developmental study of emotionality in puppies under conditions of stress. Unpublished manuscript, The Jackson Lab., Bar Harbor, Maine.

Chance, M. R. A. 1962. Social behavior and primate evolution. In M. F. A. Montagu (ed.), Culture and the Evolution of Man, p. 84-130. Oxford Univ. Press, New York.

Chateau, J. 1954. L' enfant et le jeu. Scarabee, Paris. [New edition, 1967.]

Chepko, B. D. 1971. A preliminary study of the effects of play deprivation on young goats. $Z$. Tierpsychol., 28: 517-528.

Clark, A. H., S. M. WYon, and M. P. M. Richards. 1969. Free-play in nursery school children. J. Child Psychol. Psychiat., 10: 205-216.

CRook, J. H. 1970. The socio-ecology of primates. In J. H. Crook (ed.), Social Behavior in Birds and Mammals, p. 103-166. Academic Press, New York.

Cullen, J. M. 1966. Ritualization of animal activities in relation to phylogeny, speciation, and ecology: Reduction of ambiguity through ritualization. Phil. Trans. Roy. Soc. Lond., Series B., 251: 363-374.

1972. Some principles of animal communication. In R. A. Hinde (ed.), Non-Verbal Communication, p. 101-125. Cambridge Univ. Press, New York.

Darling, F. 1937. A Herd of Red Deer. Oxford Univ. Press, New York.

Darwin, C. 1872. The Expressions of the Emotions in Man and Animals. D. Appleton and Co., New York. [1965, Univ. of Chicago Press.]

DENENBERG, V. H. (ed.). 1972. The Development of Behavior. Sinauer Assoc., Conn.

EisenberG, J. F. 1966. The social organization of mammals. Handb. Zool., Berlin, 8 (10), 7: 1-92.

EISENBERG, L. 1962. The human nature of human nature. Science, 176: 123-128.

ESPMARK, Y. 1969. Mother-young relations and development of behaviour in roe deer (Capreolus capreolus L.). Viltrevy, $6(6)$ : 462-540.

- 1971. Mother-young relationship and ontogeny of behaviour in reindeer (Rangifer tarandus L.). Z. Tierpsychol., 29: 42-81.

Estes, R. D., and J. GodDard. 1967. Prey selection and hunting behavior of the African wild dog. J. Wildl. Management, 31: 52-70.

EткіN, W. 1964. Theories of socialization and communication. In W. Etkin (ed.), Social Behavior and Organization Among Vertebrates, p. 167-205. Univ. of Chicago Press, Chicago.

EwER, R. F. 1968. Ethology of Mammals. Plenum Press, New York. 
Farentinos, R. C. 1971. Some observations on the play behavior of the Stellar sea lion (Eumetopias jabata). Z. Tierpsychol., 28: 428-438.

Fiske, J. 1875. Outlines of Cosmic Philosophy. Houghton Mifflin, Boston.

Focden, S. C. L. 1971. Mother-young behaviour at Grey seal breeding beaches. J. Zool., Lond., 164: 61-92.

Foss, B. M. (ed.). 1961. Determinants of Infant Behaviour, Vol. 1. Methuen, London.

- 1963. Determinants of Infant Behaviour. Vol. 2. Methuen, London.

- 1965. Determinants of Infant Behaviour. Vol. 3., Methuen, London.

- 1969. Determinants of Infant Behaviour. Vol. 4., Methuen, London.

Fox, M. W. 1968. Ethology: An overview. In M. W. Fox (ed.), Abnormal Behavior in Animals, p. 21-43. W. B. Saunders, Philadelphia.

- 1969. Ontogeny of prey-killing behavior in Canidae. Behaviour, 35: 259-272.

- 1970a. A comparative study of the development of facial expression in canids: wolf, coyote and foxes. Behaviour, 36: 49-73.

- 1970b. Neurobehavioral development and the genotype-environment interaction. Quart. Rev. Biol., 45: 131-147.

- 1971a. Integrative Development of Brain and Behavior in the Dog. Univ. of Chicago Press, Chicago.

- 1971b. Behaviour of Wolves, Dogs and Related Canids. Cape, London.

- 1971c. Towards a comparative psychopathology. Z. Tierpsychol., 29: 416-437.

- 1972. Evolution of social behavior in canids. In M. W. Fox (ed.), Social Ecology and Behavior of Canids. Van Nostrand and Co., New York, in press.

Fox, M. W., and A. Clark. 1971. The development and temporal sequencing of agonistic behavior in the coyote (Canis latrans). Z. Tierpsychol. 28: 262-278.

Fuller, J. L. 1967. Experiential deprivation and later behavior. Science, 158: 1645-1652.

GilberT, B. K. 1968. Development of social behavior in the fallow deer (Dama dama). $Z$. Tierpsychol., 25: 867-876.

Girmore, J. B. 1966. Play: A special behavior. In R. N. Haber (ed.), Current Research in Motivation, p. 343-355. Holt, Rhinehart, and Winston, New York.

Glickman, S. E., and R. W. Sroges. 1966. Curiosity in zoo animals. Behaviour, 26: 151-188,

Gould, E. 1971. Studies of maternal-infant communication and development of vocalizations in the bats Myotis and Eptesicus. Comm. Behav. Biol., 5: 263-313.
Grant, E. C. 1963. An analysis of the social behaviour of the male laboratory rat. Behaviour, 21: 260-281.

Groos, K. 1898. The Play of Animals.. D. Appleton, New York.

Grota, L. J., V. H. Denenberg, and M. X. Zarrow. 1966. Normal vs. caeserian delivery: Effects on survival probability, weaning weight, and open field activity. J. Comp. Physiol. Psychol., 61: 159-160.

Gulick, L. H. 1920. A Philosophy of Play. Ch. Scribner, New York.

HABER, G. C. 1968. The social structure and behavior of an Alaskan wolf population. Unpublished Master's thesis, Northern Michigan Univ.

Hafez, E. S. E., M. W. Schein, and R. Ewbank. 1969. The behaviour of cattle. In E. S. E. Hafez (ed.), The Behaviour of Domestic Animals, p. 235-295. Williams and Wilkins, Baltimore.

HALL, K. R. L. 1967. Social interactions of the adult male and adult females of a patas monkey group. In S. A. Altmann (ed.), Social Communication Among Primates, p. 261-280. Univ. of Chicago Press, Chicago.

Harlow, H. F. 1969. Age-mate or peer affectional systems. In D. S. Lehrman, R. A. Hinde, and E. Shaw (eds.), Advances in the Study of Behavior, Vol. 2, p. 333-383. Academic Press, New York.

1971. Learning To Love.. Albion Publ. Co., San Francisco.

Harlow, H. F., and M. K. Harlow. 1961. A study of animal affection. Natur. Hist., 70: 48-55. and 1966. Learning to love. $\mathrm{Am}$. Scientist, 54: 244-272.

Harlow, H. F., and S. J. Suomi. 1971. Social recovery by isolation-reared monkeys. Proc. Nat. Acad. Sci., 68: 1534-1538.

HARPER, L. V. 1970. Ontogenetic and phylogenetic functions of the parent-offspring relationship in mammals. In D. S. Lehrman, R. A. Hinde, and E. Shaw (eds.), Advance in the Study of Behavior, Vol. 3., p. 75-115. Academic Press, New York.

Heвв, D. O. 1949. The Organization of Behavior. John Wiley, New York.

- 1953. Heredity and environment in animal behavior. Brit. J. Anim. Behav., 1: 43-47.

Heckhausen, H. 1964. Entwurt einer Psychologie des Spielens. Psychol. Forsch., 27: 225-243.

Henderson, L. 1972. On mental energy. Brit. J. Psychol., 63: 1-7.

Herron, R. E., and B. Sutton-Smith (eds.). 1971. Child's Play. John Wiley, New York. 
Нıмшich, W. A. 1971. Age equivalence and related problems in comparative developmental neurochemistry. Paper delivered at the first meeting of the International Society for Developmental Psychobiology, Washington, D.C.

Hinde, R.A. 1960. Energy models of motivation. Symp. Soc. Exp. Biol. Lond., 14: 199-213.

- 1965. Rhesus monkey aunts. In B. M. Foss (ed.), Determinants of Infant Behaviour III, p. 67-75. Methuen, London.

- 1971a. Development of social behavior. In A. M. Schrier and F. Stollnitz (eds.), Behavior of Nonhuman Primates, Vol. 3, p. 1-68. Academic Press, New York.

- 1971b. Some problems in the study of the development of behavior. In E. Tobach, L. R. Aronson, and E. Shaw (eds.), The Biopsychology of Development, p. 411-432. Academic Press, New York.

Hopf, S. 1970. Report on a hand-reared squirrel monkey (Saimiri sciureus). Z. Tierpsychol., 27: 610-621.

HoRwich, R. H. 1972. The ontogeny of social behavior in the gray squirrel (Sciurus carolinensis). Z. Tierpsychol., 8 (Suppl.): 1-103.

Huizinga, J. 1939. Homo Ludens: A Study of the Play Element in Culture. Pantheon, Amsterdam. [Reprinted in 1955 by Beacon Press, Boston.]

Hutr, S. J., and C. Hutr. 1970. Direct Observation and Measurement of Behavior. C. C Thomas, Springfield.

ItARD, J. M. G. 1962. The Wild Boy of Aveyron. Appleton-Century-Crofts, New York. [Originally published in 1801.]

JAY, P. C. 1962. Aspects of maternal behavior among langurs. Ann. N.Y. Acad. Sci., 102: $468-476$.

- 1963. Mother-infant relations in langurs. In H. L. Rheingold (ed.), Maternal Behavior in Mammals, p. 282-304. John Wiley, New York.

- 1965. The common langur of North India. In I. DeVore (ed.), Primate Behavior, p. 197249. Holt, Rhinehart, and Winston, New York.

Jenson, G. D., R. A. Bobbitt, and B. N. Gordon. 1968. Sex differences in the development of independence of infant monkeys. Behaviour, 30: 1-14.

Jolly, A. 1972. The Evolution of Primate Behavior. Macmillan, New York.

Jonas, D., and D. Klein. 1970. Man-Child: $A$ Study of the Infantilization of Man. McGraw Hill, New York.

KagaN, J., and F. H. BEACH. 1953. Effects of early experience on mating behavior in male rat. $J$. Comp. Physiol. Psychol., 46: 204-208.
Kaufman, I. C. 1960. Some theoretical implications from animal behavior studies for the psychoanalytic concepts of instinct, energy, and drive. Intern. J. Psychoanal., 41: 318-325.

KAWAI, M. 1958. On the system of social ranks in a natural troop of Japanese monkeys. I. Basic rank and dependent rank. Primates, 1: 111-130.

Klopfer, P. H. 1972. Patterns of maternal care in lemurs. II. Effects of group size and early separation. Z. Tierpsychol., 30: 277-296.

Koepke, J. E., and K. H. Pribham. 1971. Effect of milk on the maintenance of sucking behavior in kittens from birth to six months. J. Comp. Physiol. Psychol., 75: 363-377.

KorNer, A. 1971. Individual differences at birth: implications for early experience and later development. Am. J. Orthopsychiat., 41: 608618.

Kovach, J. K. 1971. Ethology in the Soviet Union. Behaviour, 39: 237-265.

Kummer, H. 1971. Primate Societies. Aldine, Chicago.

LABarba, R. C., and J. L. White. 1971. Litter size variations and emotional reactivity in BALB/c mice. J. Comp. Physiol. Psychol., 75: 254-257.

Latta, J., S. Hopf, and D. Ploog. 1967. Observations on mating behavior and sexual play in the squirrel monkey (Saimiri sciureus). Primates, 8: 229-246.

LEACH, G. M. 1972. A comparison of the social behaviour of some normal and problem children. In N. G. Blurton Jones (ed.), Ethological Studies of Child Behaviour, p. 249-281. Cambridge Univ. Press, Cambridge.

Lehrman, D. S. 1953. A critique of Konrad Lorenz's theory of instinctive behavior. Quart. Rev. Biol., 28: 337-363.

- 1962. Interaction of hormonal and experiential influences on development. In E. L. Bliss (ed.), Roots of Behavior, p. 142-156. Hafner Publ. Co., New York.

1970. Semantic and conceptual issues in the nature-nurture problem. In L. R. Aronson, E. Tobach, D. S. Lehrman, and J. S. Rosenblatt (eds.), Development and Evolution of Behavior, p. 17-52. Freeman, San Francisco.

Lehrman, D. S., and J. S. Rosenblatt. 1971. The study of behavioral development. In $\mathrm{H}$. Moltz (ed.), Ontogeny of Vertebrate Behavior, p. 1-27. Academic Press, New York.

Lerwill, C. J., and P. Makings. 1971. The agonistic behaviour of the golden hamster Mesocricetus auratus (Waterhouse). Anim. Behav., 19: 714-721. 
Levy, D. 1943. Maternal Overprotection. Columbia Univ. Press, New York.

LewIN, K. 1933. Environmental forces. In C. Murchinson (ed.), A Handbook of Child Psychology, p. 590-625. Clark Univ. Press, Worcester.

Leyhausen, P. 1965. Über die Funktion der relativen Stimmungs hierarchie Dargestellt am Beispiel der phylogenetischen und ontogenetischen Entwicklung des Beutesfangs van Raubtieren. Z. Tierpsychol., 22: 412-494.

Loizos, C. 1966. Play in mammals. Symp. Zool. Soc. Lond., 18: 1-9.

- 1967. Play behavior in higher primates: A review. In D. Morris (ed.), Primate Ethology, p. 226-282. Aldine, Chicago.

LORE, R. K. 1968. Activity-drive hypothesis: Effects of activity restriction. Psychol. Bull., 70: 566574.

Lorenz, K. Z. 1950. The comparative method in studying innate behavior patterns. Symp. Soc. Exp. Biol., 4: 221-268.

- 1956. Plays and vacuum activities. In L'instinct dans le comportement des animaux et de l'homme, p. 633-645. Masson, Paris.

- 1961. Phylogenetische Anpassung und adaptive Modifikations des Verhaltens. Z. Tierpsychol., 18: 139-187.

- 1965. Evolution and Modification of Behavior. Univ. of Chicago Press, Chicago.

Lowenfeld, M. 1967. Play in Childhood. John Wiley, New York. [Originally published in 1935.]

Ludwig, J. 1965. Beobachtungen über das Spiel bei Boxern. Z. Tierpsychol., 22: 813-838.

Lyons, J. 1972. Human language. In R. A. Hinde (ed.), Non-Verbal Communication, p. 49-85. Cambridge Univ. Press, New York.

MacNamara, J. 1972. Cognitive basis of language learning in infants. Psychol. Rev., 79: 1-13.

Manning, A. 1971. Evclution of behavior. In J. L. McGaugh (ed.), Psychobiology, p. 1-52. Academic Press, New York.

MARLER, P. 1967. Animal communication signals. Science, 157: 769-774.

Mason, W. A. 1960. The effects of social restriction on the behavior of rhesus monkeys: I. Free social behavior. J. Comp. Physiol. Psychol., 53: 582-589.

- 1965. The social development of monkeys and apes. In I. Devore (ed.), Primate Behavior, p. 514-543. Holt, Rinehart, and Winston, New York.

1968. Scope and potential of primate research. In J. H. Masserman (ed.), Animal and Human, p. 101-118. Grune and Stratton, New York.
1971. Field and laboratory studies of social organization in Saimiri and Callicebus. In L. A. Rosenblum (ed.), Primate Behavior: Developments in Field and Laboratory Research, Vol. 2, p. 107-137. Academic Press, New York.

Maurus, M., and D. Ploog. 1971. Social signals in squirrel monkeys: Analysis by cerebral radio stimulation. Exp. Brain Res., 12: 171-183.

McBride, G. 1971. The nature-nurture problem in social evolution. In J. F. Eisenberg, W. S. Dillon, and S. D. Ripley (eds.), Man and Beast: Comparative Social Behavior, p. 35-36. Smithsonian Institution Press, Washington, D. C.

McGrew, W. C., 1972. An Ethological Study of Children's Behavior. Academic Press, New York.

Mech, D. L. 1970. The Wolf. The Natural History Press, New York.

MEIER, G. W. 1964. Behavior of infant monkeys: Differences attributable to mode of birth. Science, 143: 968-970.

-1965. Other data on the effects of social isolation during rearing upon adult reproductive behavior in the rhesus monkey (Macaca mulatta). Anim. Behav., 13: 228-231.

1971. Hypoxia. In E. Ferchtgott (ed.), Pharmacological and Biophysical Agents and Behavior, p. 99-142. Academic Press, New York.

Meier, G. W., and C. Garcia-Rodriguez. 1966. Continuing behavioral differences in infant monkeys as related to mode of delivery. Psychol. Rep., 19: 1219-1225.

Melzack, R. 1952. Irrational fears in the dog. Canad. J. Psychol., 6: 141-147.

MelzaCK, R., and K. Burns. 1965. Neurophysiological effects of early sensory restriction. Exp. Neurol., 13: 163-175.

Melzack, R., and T. H. Scotr. 1957. The effects of early experience on the response to pain. J. Comp. Physiol. Psychol., 50: 155-161.

Meyer-Holzapfel, M. 1956a. Über die Bereitschaft zu Spiel- und Instinkthandlungen. $Z$. Tierpsychol., 13: 442-462.

- 1956b. Das Spiel bei Saugetieren. Handb. Zool., Berlin, 8 (10), 5: 1-36.

Millar, S. 1968. The Psychology of Play. Penguin Books, Baltimore.

Miller, R. E., W. F. Gaul, and I. A. Mirsky. 1967. The communication of affects between feral and socially isolated monkeys. J. Pers. Soc. Psychol., 7: 231-239.

MIRsky, I. A. 1968. Discussion of Mason's "Scope and potential of primate research." In J. $\mathbf{H}$. Masserman (ed.), Animal and Human, p. 112118. Grune and Stratton, New York. 
Mrtchell, G. D. 1969. Paternalistic behavior in primates. Psychol. Bull., 71: 399-417.

Mitchell, G. D., E. J. Raymond, G. G. RuppenTHAL, and H. F. HARLow. 1966. Long-term effects of total isolation upon behavior of rhesus monkeys. Psychol. Rep. 18: 567-580.

Moltz, H. (ed.). 1971a. The Ontogeny of Vertebrate Behavior. Academic Press, New York.

- 1971b. The ontogeny of maternal behavior in some selected mammalian species. In $\mathbf{H}$. Moltz (ed.), The Ontogeny of Vertebrate Behavior, p. 263-313. Academic Press, New York.

Montagu, M. F. A. 1962. Time, morphology, and neoteny in the evolution of Man. In M. F. A. Montagu (ed.), Culture and the Evolution of Man, p. 324-342. Oxford Univ. Press, New York.

MORrIS, D. 1957. "Typical intensity" and its relation to the problem of ritualization. $B e-$ haviour, 11: 1-12.

- 1966. Abnormal rituals in stress situations: The rigidification of behavior. Phil. Trans. Roy. Soc. Lond., Series B., 251: 327-330.

Morton, J. R. C. 1968. Effects of early experience, "handling" and "gentling" in laboratory animals. In M. W. Fox (ed.), Abnormal Behavior in Animals, p. 261-292. W. B. Saunders, Phila.

Muller-Schwarze, D. 1968. Play deprivation in deer. Behaviour, 31: 144-162.

1971. Ludic behavior in young mammals.

In M. B. Sterman, D. J. McGinty, and A. M. Adinolfi (eds.), Brain Development and Behavior, p. 229-249. Academic Press, New York.

Mussen, P. H. (ed.). 1970. Carmichaels' Manual of Child Psychology. Vols. 1 and 2. John Wiley, New York.

Nelson, K. 1964. The temporal patterning of courtship behavior in the glandulocaudine fishes. Behaviour, 24: 90-146.

Newton, G., and S. Levine (eds.). 1968. Early Experience and Behavior: The Psychobiology of Development.. C. C. Thomas, Springfield.

Nissen, H. W. 1951. Phylogenetic comparison. In S. S. Stevens (ed.), Handbook of Experimental Psychology, p. 347-386. John Wiley, New York.

Piaget, J. 1951. Play, Dreams, and Imitation in Childhood. Norton, New York.

Ploog, D. 1967. The behavior of squirrel monkeys (Saimiri sciureus) as revealed by sociometry, bioacoustics, and brain stimulation. In S. A. Altmann (ed.), Social Communication Among Primates, p. 149-184. Univ. of Chicago Press, Chicago.

1969. Early communication in squirrel monkeys. In R. J. Robinson (ed.), Brain and Early Behavior, p. 269-303. Academic Press, New York.
- 1970. Social communication among animals. In F. O. Schmitt (ed.), The Neurosciences: $\boldsymbol{A}$ Study Program II, p. 349-361. Rockefeller Univ. Press, New York.

PoIrer, F. E. 1970. The Nilgiri langur of South India. In L. A. Rosenblum (ed.), Primate Behavior: Developments in Field and Laboratory Research. Vol. 1., p. 251-383. Academic Press, New York.

Poole, T. B. 1966. Aggressive play in polecats. Symp. Zool. Soc. Lond., 18: 23-44.

- 1967. Aspects of aggressive behavior in polecats. Z. Tierpsychol., 24: 351-369.

- 1972. Diadic interactions between pairs of male polecats (Mustela furo and Mustela furo $\times M$. putorius hybrids) under standardised environmental conditions during the breeding season. Z. Tierpsychol., 30: 45-58.

Pratt, C. L., and G. P. Sackett. 1967. Selection of social partners as a function of peer contact during rearing. Science, 155: 1133-1135.

Ramsay, A. 1969. Time, space, and hierarchy in zoosemiotics. In T. A. Sebeok and A. Ramsay (eds.), Approaches to Animal Communication, p. 179-199. Humanities Press, New York.

Ransom, T. W., and B. S. Ransom. 1971. Adult male-infant relations among Baboons (Papio anubis). Folia Primatol., 16: 179-195.

Reynierse, J. H. 1971. Agonistic behavior in mongolian gerbils. Z. Tierpsychol., 29: 175-179.

Rheingold, H. L. 1963. Maternal behavior in the dog. In H. L. Rheingold (ed.), Maternal Behavior in Mammals, p. 169-202. John Wiley, New York.

Rosenblum, L. 1971. The ontogeny of motherinfant relations in macaques. In $\mathbf{H}$. Moltz (ed.), The Ontogeny of Vertebrate Behavior, p. 315-367. Academic Press, New York.

Rue, L. L. 1969. The World of the Red Fox. Lippincott, New York.

Russell, E. 1970. Observations on the behavior of the red kangaroo (Megaleia rufa) in captivity. Z. Tierpsychol., 27: 384-404.

Russell, W. M. S., A. P. Mead, and J. S. Hayes. 1954. A basis for the quantitative study of the structure of behavior. Behaviour, 6: 153205.

SAcketr, G. P. 1970. Unlearned responses, differential rearing experiences, and the development of social attachments by rhesus monkeys. In L. A. Rosenblum (ed.), Private Behavior: Developments in Field and Laboratory Research. Vol. I., p. 111-140. Academic Press, New York.

Schaffer, H. R. (ed.). 1971 The Origins of Human Social Relations. Academic Press, New York. 
Schaller, G. B. 1963. The Mountain Gorilla. Univ. of Chicago Press, Chicago.

Schassburger, R. M. 1968. Behavioral notes on a hand-rcared male timber wolf (Canis lupus) I: Daily rhythms, behavioral sequences and some predictable behavioral patterns, and some discussion of some behavioral patterns and social relationships. Unpublished manuscript.

Schlosberg, H. 1947. The concept of play. Psychol. Rev., 54: 229-231.

Schneirla, T. C. 1966. Behavioral development and comparative psychology. Quart. Rev. Biol., 41: 282-302.

Schönberner, D. 1965. Beobachtungen zur Fortpflanzungsbiologie des Wolfes, Canis lupus. Z. Saugetierkunde, 30: 171-178.

Scott, J. P. 1958. Aggression. Univ. of Chicago Press, Chicago.

- 1968. Early Experience and the Organization of Behavior. Brooks/Cole, California.

Scott, J. P., and F. H. Bronson. 1964. Experimental exploration of the et-epimeletic or care-soliciting behavioral system. In $\mathbf{P}$. $\mathbf{H}$. Leiderman and D. Shapiro (eds.), Psychobiological Approaches to Social Behavior, p. 174-193. Stanford Univ. Press, Stanford.

Seay, B., R. S. Schlottman, and B. Thorne. 1970. Maternal and filial behavior in monkeys. Develop. Psychol., 3: 66-72.

Sheppard, D. H., and S. M. Yoshida. 1971. Social behavior in captive Richardson's ground squirrels, J. Mammal., 52: 793-799.

Silver, H., and W. T. Silver. 1969. Growth and behavior of the coyote-like canid of northern New England with observations on canid hybrids. Wildlife Mono., No. 17: 1-41.

SLEET, D. A. 1971. Interdisciplinary Research Index on Play. Univ́ of Toledo Press, Toledo.

Slonim, A. D. 1969. The ecological-physiological approach to problems of animal behavior. In M. Cole and I. Maltzman (eds.), A Handbook of Contemporary Soviet Psychology, p. 811-829. Basic Books, New York.

- 1972. Ecophysiologic studies of innate behavior in mammals. Int. J. Psychobiol., 2: 37-64.

Smith, P. K., and K. Connelly 1972. Patterns of play and social interaction in pre-school children. In N. G. Blurton Jones (ed.), Ethological Studies of Child Behaviour, p. 65-95. Cambridge Univ. Press, Cambridge.

Spencer-Booth, Y. 1970. The relationships between mammalian young and conspecifics other than mothers and peers. In D. S. Lehrman, R. A. Hinde, and E. Shaw (eds.), Advances in the Study of Behavior. Vol. 3., p. 119-194. Academic Press, New York.

Stanley, M. 1971. An ethogram of the hopping mouse (Notomys alexis). Z. Tierpsychol., 29: 225-258.

Steiner, A. L. 1971. Play activity of Columbian ground squirrels. Z. Tierpsychol., 28: 247-261.

Stephenson, W. 1967. The Play Theory of Mass Communication. Univ. of Chicago Press, Chicago.

Struhsaker, T. T. 1967. Auditory communication among vervet monkeys (Cercopithecus aethiops). In S. A. Altmann (ed.), Social Communication Among Primates, p. 281-324. Univ. of Chicago Press, Chicago.

Tembrock, G. 1957. Spielverhalten beim Rotfuchs. Zool. Beitr. Berl., 3: 423-496. [English translation by B. Piddack.]

Thoman, E. B., C. R. Barnett, and P. H. LeiderMAN. 1971. Feeding behaviors of newborn infants as a function of parity of the mother. Child Develop., 42: 1471-1483.

Thompson, W. R., and W. Heron. 1954. Exploratory behavior in normal and restricted dogs. J. Comp. Physiol. Psychol., 47: 77-82.

Thorpe, W. H. 1966. Ritualization in ontogeny: I. Animal Play. Phil. Trans. Roy. Soc. Lond., Series B., 251: 311-319.

Tinbergen, N. 1951. The Study of Instinct. Oxford Univ. Press, Oxford.

- 1963. On aims and methods of ethology. Z. Tierpsychol., 20: 410-433.

Tisza, V. B., I. Hurwitz, and K. Angoff. 1970. The use of a play program by hospitalized children. J. Am. Acad. Child. Psychiat. 9: 515-531.

ToвAch, E., and T. C. SchneIrLA. 1968. The biopsychology of social behavior of animals. In R. E. Cooke and S. Levin (eds.), Biologic Basis of Pediatric Practice, p. 68-82. McGrawHill, New York.

Tobach, E., L. R. Aronson, and E. Shaw (eds.). 1971. The Biopsychology of Development. Academic Press, New York.

VAN HoofF, J. 1962. Facial expression in higher primates. Symp. Zool. Soc. Lond., 8: 97-125. 1967. The facial displays of the catarrhine monkeys and apes. In D. Morris (ed.), Primate Ethology, p. 9-88. Aldine, Chicago.

1972. A comparative approach to the phylogeny of laughter and smiling. In $\mathbf{R}$. A. Hinde (ed.), Non-Verbal Communication, p. 209-241. Cambridge Univ. Press, New York.

VAN LAWICK-GOODALL, J. 1968. The behaviour of free-living chimpanzees in the Gombe Stream Reserve. Anim. Behav. Mono., 1 (3): 161-311. 
1971. Some aspects of mother-infant relationships in a group of wild chimpanzees. In H. R. Schaffer (ed.), The Origins of Human Social Relations, p. 115-128, Academic Press, New York.

Vine, I. 1970. Communication by facial-visual signals. In J. H. Crook (ed.), Social Behavior in Birds and Mammals, p. 279-354. Academic Press, New York.

WAELDER, R. 1933. The psychoanalytic theory of play. Psychoanal. Quart., 2: 208-224.

Welker, W. I. 1961. An analysis of exploratory and play behavior in animals. In D. W. Fiske and S. R. Maddi (eds.), Functions of Varied Experience, p. 278-325. Dorsey Press, Illinois. 1971. Ontogeny of play and exploratory behaviors: A definition of problems and a search for new conceptual solutions. In $\mathbf{H}$. Moltz (ed.), The Ontogeny of Vertebrate Behavior, p. 171-228. Academic Press, New York.
Wickler, W. 1970. Regressionen als normale Elemente des Sozialverhaltens. Praxis der Psychother., 15: 150-151.

Wiepkema, P. R. 1961. An ethological analysis of the reproductive behavior of the bitterling (Rhodeus amarus Bloch). Arch. Neerl. Zool., 14: 103-199.

Wolfheim, J. H., G. D. Jensen, and R. A. Bobbitt. 1970. Effects of group environment on the mother-infant relationship in pigtailed monkeys (Macaca nemestrina). Primates, 11: 119124.

Wootton, R. J. 1972. The behaviour of the male Three-spined stickleback in a natural situation: A quantitative description. Behaviour, 41: 232-241.

YeAton, R. I. 1972. Social behavior and social organization in Richardson's ground squirrel (Spermophilus richardsonii) in Saskatchewan. J. Mammal., 53: 139-147. 